\title{
Endonuclease 8-Like 3
}

National Cancer Institute

\section{Source}

National Cancer Institute. Endonuclease 8-Like 3. NCI Thesaurus. Code C105834.

Endonuclease 8-like 3 ( $605 \mathrm{aa}, \sim 68 \mathrm{kDa}$ ) is encoded by the human NEIL3 gene. This protein plays a role in binding and repair of single-stranded DNA. 